\title{
Synthesis of a mimic for the heterogeneous surface of core 2 sialoglycan-linked glycoprotein
}

\author{
Yutaka Takano, Hironobu Hojo,* Naoya Kojima, and Yoshiaki Nakahara*
}

\section{Experimental}

All solid-phase reactions were performed at room temperature in the capped polypropylene test tubes with stirring on a vortex tube-mixer. Ninhydrin test was run to monitor the efficiency in each condensation step. HPLC was performed using Mightysil RP-18 (150 x $4.6 \mathrm{~mm}$ for analysis and $250 \times 10 \mathrm{~mm}$ for preparation, Kanto Chemical Co.). Amino acids were analyzed on a Hitachi L-8500 amino acid analyzer. Fmoc CLEAR amide resin and Rink amide resin were purchased from Peptide Institute Inc. and NOVA Biochem, respectively. Sialyltransferases $[\square 2,3-(\mathrm{N})$-sialyltransferase, rat, recombinant, and $\square 2,3-(\mathrm{O})$-sialyltransferase, rat, recombinant] and CMP-sialic acid were purchased from CALBIOCHEM. The yields of synthetic glycopeptides were determined by amino acid analysis after the samples were hydrolyzed in a sealed tube with $20 \% \mathrm{HCl}$ and $0.5 \%$ phenol at $150{ }^{\circ} \mathrm{C}$ for $2 \mathrm{~h}$.

Glycopeptide 5. Commercial $N$-Fmoc CLEAR amide resin $(285 \mathrm{mg}, 0.1 \mathrm{mmol}$ ) was stirred with $20 \%$ piperidine/NMP $(3 \mathrm{ml})$ for $2 \mathrm{~min}$ and filtered. The resin was again treated with $20 \%$ piperidine/NMP ( $3 \mathrm{ml}$ ) for $5 \mathrm{~min}$ to complete $\mathrm{N}$-deprotection. To the resin were added Fmoc-Gly- $\mathrm{SCH}_{2} \mathrm{CH}_{2} \mathrm{CO}_{2} \mathrm{H}$ (154 mg, 0.4 $\mathrm{mmol}), 1 \mathrm{M} \mathrm{DCC} / \mathrm{NMP}(1 \mathrm{ml}, 1.0 \mathrm{mmol})$, and 1M HOBt/NMP $(1 \mathrm{ml}, 1.0 \mathrm{mmol})$. The mixture was stirred for $1 \mathrm{~h}$ and filtered. The resin was washed successively with NMP and $\mathrm{MeOH}-\mathrm{CH}_{2} \mathrm{Cl}_{2}$ (1:1). The unreacted amino group on the resin was acetylated with $10 \% \mathrm{Ac}_{2} \mathrm{O}-5 \%$ DIEA/NMP $(3 \mathrm{ml})$ for $5 \mathrm{~min}$. The resin was washed with NMP and $N$-deprotected by stirring with a mixture of 1-methylpyrrolidinehexamethyleneimine-HOBt-NMP-DMSO (50:4:4:71:71, $3 \mathrm{ml}$ ) for $3 \mathrm{~min}$. After filtration, the resin was again stirred with the same reagent mixture for $10 \mathrm{~min}$. To a suspension of the resin in THF $(3 \mathrm{ml})$, was added Tsoc-Thr(Bn)-OPfp (115 mg, $0.2 \mathrm{mmol})$ in three portions at the intervals of $15 \mathrm{~min}$. The mixture was further stirred for $15 \mathrm{~min}$ and filtered. The resin was washed with NMP and $\mathrm{CH}_{2} \mathrm{Cl}_{2}$, and then reacted with Fmoc$\operatorname{Ser}\left(\mathrm{Bu}^{\mathrm{t}}\right)-\mathrm{F}(92 \mathrm{mg}, 0.24 \mathrm{mmol})$ in $\mathrm{CH}_{2} \mathrm{Cl}_{2}(3 \mathrm{ml})$ by addition of $1 \mathrm{M}$ TBAF/THF (10 $\left.\square \mathrm{l}, 0.01 \mathrm{mmol}\right)$ and DIEA (42 $\square$ l, $0.44 \mathrm{mmol}$ ) for $1.5 \mathrm{~h}$. Filtration followed by washing with $\mathrm{CH}_{2} \mathrm{Cl}$, and NMP, and N-capping afforded the tripeptide-linked resin, from which $N$-Fmoc group was cleaved by treatment with the above mild base mixture. Then Fmoc-Thr(But)-OH $(0.4 \mathrm{mmol})$, Fmoc-Glu(OBu$)-\mathrm{OH}(0.4 \mathrm{mmol})$ and Fmoc-Leu-OH $(0.4 \mathrm{mmol})$ were condensed to the resin by using DCC $(0.4 \mathrm{mmol})-\mathrm{HOBt}(0.4 \mathrm{mmol})$ in NMP as described above.

A part of the $N$-deprotected hexapeptide-resin (25 पmol) was stirred with $4 \mathbf{a}$ (99 mg, $52 \square \mathrm{mol}$ ), HATU (19 mg, $49 \square \mathrm{mol})$, and DIEA (14 $\square \mathrm{l}, 78 \square \mathrm{mol})$ in NMP $(0.5 \mathrm{ml})$ at $50{ }^{\circ} \mathrm{C}$ for $4 \mathrm{~h}$, before the mixture was filtered. The resulting resin was washed with NMP and $\mathrm{MeOH}-\mathrm{CH}_{2} \mathrm{Cl}_{2}$ (1:1) and $N$-deprotected. The $N$-capping process was omitted after introduction of the hydroxyl group-containing tetrasaccharide unit. Further elongation of the peptide was performed with Fmoc-Asp(OBu $\left.{ }^{t}\right)-\mathrm{OH}(0.1 \mathrm{mmol} \times 2)$, Fmoc-Thr( $\left.\mathrm{Bu}^{\mathrm{t}}\right)-\mathrm{OH}(0.1$ 
mmol x 2), Fmoc-Ala-OH $(0.1 \mathrm{mmol} \times 2)$, Fmoc-Met-OH $(0.1 \mathrm{mmol} \times 2)$ in the presence of DCC $(0.1$ mmol)-HOBt $(0.1 \mathrm{mmol})$ in NMP. For these four amino acids the coupling reaction was accomplished by employing a double-coupling procedure for $12 \mathrm{~h}$ at room temperature. Ninhydrin test proved that the coupling reactions were insufficiently promoted by the usual single coupling method. Thus synthesized Fmoc-glycopeptide-resin $(55 \mathrm{mg}, 8.8 \square \mathrm{mol}$ ) was detached from the resin by stirring with reagent K [TFAphenol-deionized water-thioanisole-ethanedithiol (82.5:5:5:5:2.5), $0.7 \mathrm{ml}$ ] for $1 \mathrm{~h}$. The volatile components in the mixture were removed by blowing nitrogen. Ether was added to the residue, the mixture was centrifuged, and the ethereal layer was decanted. The precipitate was again washed with ether and centrifuged. To the precipitated mixture containing the resin residue was added a mixture of dimethylsulfide

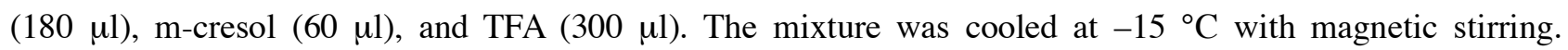
TfOH (60 $\square \mathrm{l}$ ) was added to the stirred mixture, and the mixture was stirred for $2 \mathrm{~h}$ before quenching with cooled $\left(-80^{\circ} \mathrm{C}\right)$ solution of pyridine $(120 \square \mathrm{l})$ in ether $(1 \mathrm{ml})$. The mixture was vigorously stirred for $1 \mathrm{~min}$ with a vortex mixer. The precipitate was separated by centrifugation, the ethereal layer was decanted, and the residual precipitate was washed two times with ether as above. The crude product was dissolved in $30 \%$ aq. $\mathrm{CH}_{3} \mathrm{CN}$ and chromatographed by HPLC using a preparative column of RP-18 under a gradient elution of 30$50 \% \mathrm{CH}_{3} \mathrm{CN}(0-20 \mathrm{~min}$, flow rate: $2.5 \mathrm{ml} / \mathrm{min})$ to afford 5 (2.1 $\left.\square \mathrm{mol}, 24 \%\right)$. The yield was estimated based on the data of amino acid analysis using the hydrolyzed sample derived from a part of diluted solution of whole 5. MALDI TOF MS: Calcd. for $\mathrm{C}_{89} \mathrm{H}_{134} \mathrm{~N}_{14} \mathrm{O}_{43} \mathrm{~S}_{2} \bullet \mathrm{Na} m / z$ 2173.81. Found 2173.96.

Glycopeptide 6. Commercial $N$-Fmoc Rink amide MBHA resin (342 mg, $0.25 \mathrm{mmol}$ ) was stirred with 20\% piperidine/NMP ( $3 \mathrm{ml})$ for $5 \mathrm{~min}$ and filtered. The resin was again treated with $20 \%$ piperidine/NMP $(3 \mathrm{ml})$ for $15 \mathrm{~min}$ to complete $\mathrm{N}$-deprotection. The resin was washed several times with NMP. To the resin were added Fmoc-Thr(Bu $\left.{ }^{t}\right)-\mathrm{OH}(398 \mathrm{mg}, 1.0 \mathrm{mmol}), 1 \mathrm{M}$ DCC/NMP $(1 \mathrm{ml}, 1.0 \mathrm{mmol})$, and 1M HOBt/NMP (1 ml, $1.0 \mathrm{mmol})$. The mixture was stirred for $1 \mathrm{~h}$ and filtered. The resin was washed successively with NMP and $\mathrm{MeOH}-\mathrm{CH}_{2} \mathrm{Cl}_{2}$ (1:1). The unreacted amino group on the resin was acetylated with $10 \% \mathrm{Ac}_{2} \mathrm{O}-5 \%$ DIEA/NMP ( $3 \mathrm{ml}$ ) for $5 \mathrm{~min}$. After washing with NMP, the $N$-Fmoc group was removed with piperidine, and the second amino acid building block, Fmoc-Val-OH (1.0 mmol), was condensed. Similarly, two proline and glycine residues were sequentially introduced. A part of the $N$-deprotected pentapeptide-resin (58 mg, 32 $\square \mathrm{mol})$ was reacted with $\mathbf{4 b}(118 \mathrm{mg}, 63 \square \mathrm{mol})$ in the presence of HATU (23 mg, $60 \square \mathrm{mol})$ and DIEA (17 $\square$, $95 \square \mathrm{mol})$ in NMP $(0.5 \mathrm{ml})$ at $50{ }^{\circ} \mathrm{C}$ for $4 \mathrm{~h}$. After washing with NMP and $\mathrm{MeOH}-\mathrm{CH}_{2} \mathrm{Cl}_{2}$, the resin was $N$ deprotected, reacted with Fmoc- $\operatorname{Thr}\left(\mathrm{Bu}^{\mathrm{t}}\right)-\mathrm{OH}(50 \mathrm{mg}, 125 \square \mathrm{mol})$, and finally $N$-deprotected as described above. The resin $(30 \mathrm{mg}, 8.0 \square \mathrm{mol})$ was treated with reagent $\mathrm{K}$ to detach the glycopeptide, and the resulting mixture of the product and resin was submitted to debenzylation under the conditions of low-acidity TfOH as described for $\mathbf{5}$. The fully deprotected product was purified by HPLC on a preparative RP-18 column eluted with a gradient of $7-15 \% \mathrm{CH}_{3} \mathrm{CN}(0-16 \mathrm{~min})$ to give $6(5.6 \square \mathrm{mol}, 70 \%)$. The yield was obtained by amino acid analysis. MALDI TOF MS: Calcd. for $\mathrm{C}_{57} \mathrm{H}_{96} \mathrm{~N}_{10} \mathrm{O}_{30}{ }^{\bullet} \mathrm{Na} m / z$ 1423.62. Found 1423.74.

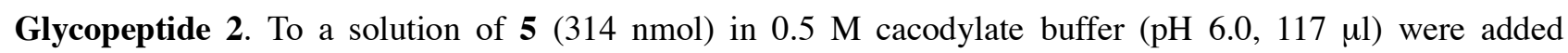


bovine serum albumin (BSA) in water ( $5 \mathrm{mg} / \mathrm{ml}, 15 \square \mathrm{l}), 0.1 \mathrm{M} \mathrm{CMP-sialic} \mathrm{acid} \mathrm{(15} \square \mathrm{l}$ ), and recombinant rat ○-Gal- $\square 1,3-G a l N A c-\square 2,3$-sialyltransferase $(2.7 \mathrm{mU})$. The mixture was incubated at $37{ }^{\circ} \mathrm{C}$ for $2 \mathrm{~h}$ and then diluted with $20 \% \mathrm{CH}_{3} \mathrm{CN}$ containing $0.1 \%$ TFA to quench the enzymatic reaction. The mixture containing the derired sialoglycopeptide was chromatographed by HPLC in the same conditions as those used for $\mathbf{5}$ to afford 2 (220 nmol, 70\%). MALDI TOF MS: Calcd. for $\mathrm{C}_{100} \mathrm{H}_{151} \mathrm{~N}_{15} \mathrm{O}_{51} \mathrm{~S}_{2} \cdot \mathrm{Na} m / z$ 2464.90. Found 2464.67.

Glycopeptide 3. To a solution of $\mathbf{6}(912 \mathrm{nmol})$ in $0.5 \mathrm{M}$ MOPS buffer ( $\mathrm{pH} 7.4,345 \square \mathrm{l}$ ) were added bovine serum albumin (BSA) in water $(5 \mathrm{mg} / \mathrm{ml}, 100 \square \mathrm{l}), 0.1 \mathrm{M}$ CMP-sialic acid (50 $\square$ l), and recombinant rat $\square-G a l-$ $\square 1,3 / 4-G l c N A c-\square 2,3$-sialyltransferase $(18.3 \mathrm{mU})$. The mixture was incubated at $37^{\circ} \mathrm{C}$ for $2 \mathrm{~h}$ before diluted with $10 \mathrm{mM} \mathrm{NH} \mathrm{NH}_{4} \mathrm{OAc}$ buffer ( $\mathrm{pH}$ 5.8) containing $2 \% \mathrm{CH}_{3} \mathrm{CN}$, and the resulting mixture was immediately chromatographed by HPLC on a preparative RP-18 column with a gradient of $4.5-18 \% \mathrm{CH}_{3} \mathrm{CN}(0-30 \mathrm{~min})$ in $10 \mathrm{mM}$ ammonium acetate buffer ( $\mathrm{pH}$ 5.8). The product thus separated from unconverted 5 was desalted by reversed phase HPLC with the acetonitrile gradient in water as used for isolation of $\mathbf{5}$ to produce $\mathbf{3}$ ( $589 \mathrm{nmol}$, 63\%). MALDI TOF MS: Calcd. for $\mathrm{C}_{68} \mathrm{H}_{113} \mathrm{~N}_{11} \mathrm{O}_{38} \mathrm{Na} m / z$ 1714.71. Found 1714.74.

Glycopeptide 1. Both segments 2 and $\mathbf{3}$ were dried overnight under vacuum at $37{ }^{\circ} \mathrm{C}$ over $\mathrm{P}_{2} \mathrm{O}_{5}$. Segment $\mathbf{3}$ $(111 \mathrm{nmol})$ was dissolved in a mixture of HOOBt $(1 \mathrm{mg})$, and DIEA (0.7 $\square \mathrm{l})$ in DMSO (100 $\square \mathrm{l})$ and added to a polypropylene microtube containing $2(80 \mathrm{nmol})$. To the magnetically stirred mixture was added $\mathrm{AgCl}(0.1$ $\mathrm{mg}$ ). The resultant mixture was stirred in the dark for $15 \mathrm{~h}$. Analyses by HPLC and MS indicated completion of the reaction. A new product appeared in the HPLC, while a part of $\mathbf{2}$ was hydrolyzed to give the Cterminal carboxylic acid in the minor fraction (Figure 1c). Then the mixture was stirred with piperidine (10 11) for $30 \mathrm{~min}$ to remove the Fmoc group. Ether $(1 \mathrm{ml})$ was added to the mixture, which was centrifuged to separate the precipitates. After removal of the ether layer by decantation, the insoluble product was again washed with ether. Washing with ether was repeated two times. The crude product was dissolved in 5\% $\mathrm{CH}_{3} \mathrm{CN}$ containing $0.1 \%$ TFA, and chromatographed by HPLC on a preparative RP-18 column as described above to afford the fraction containing $1(24 \mathrm{nmol})$. The product was further purified by HPLC using $10 \mathrm{mM}$ ammonium acetate buffer to give pure $\mathbf{1}(13 \mathrm{nmol}, 16 \%)$.

MALDI TOF MS: Calcd. for $\mathrm{C}_{150} \mathrm{H}_{246} \mathrm{~N}_{25} \mathrm{O}_{86} \mathrm{~S}(\mathrm{M}-\mathrm{H})^{-} \mathrm{m} / \mathrm{z}$ 3806.54. Found 3805.98. 

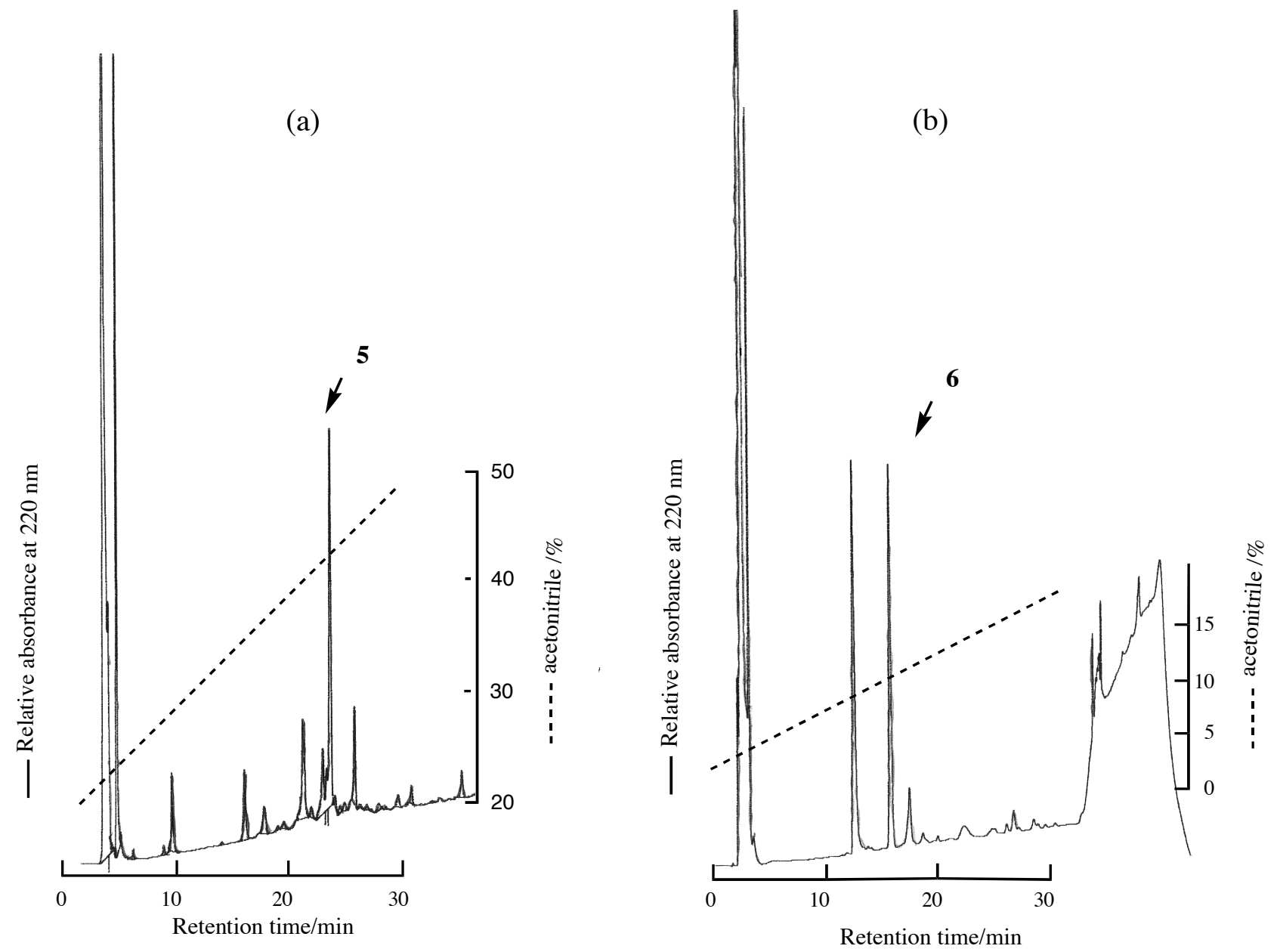

Figure 2. HPLC of glycopeptides 5 (a) and $\mathbf{6}$ (b). The peak at $13.2 \mathrm{~min}$ in (b) corresponds to the contaminant scavenger. Column: Mightysil, RP-18 (150x4.6 mm), Eluent A: distilled water containing $0.1 \%$ TFA, B: acetonitrile containing $0.1 \%$ TFA, Flow rate $1 \mathrm{ml} / \mathrm{min}$.

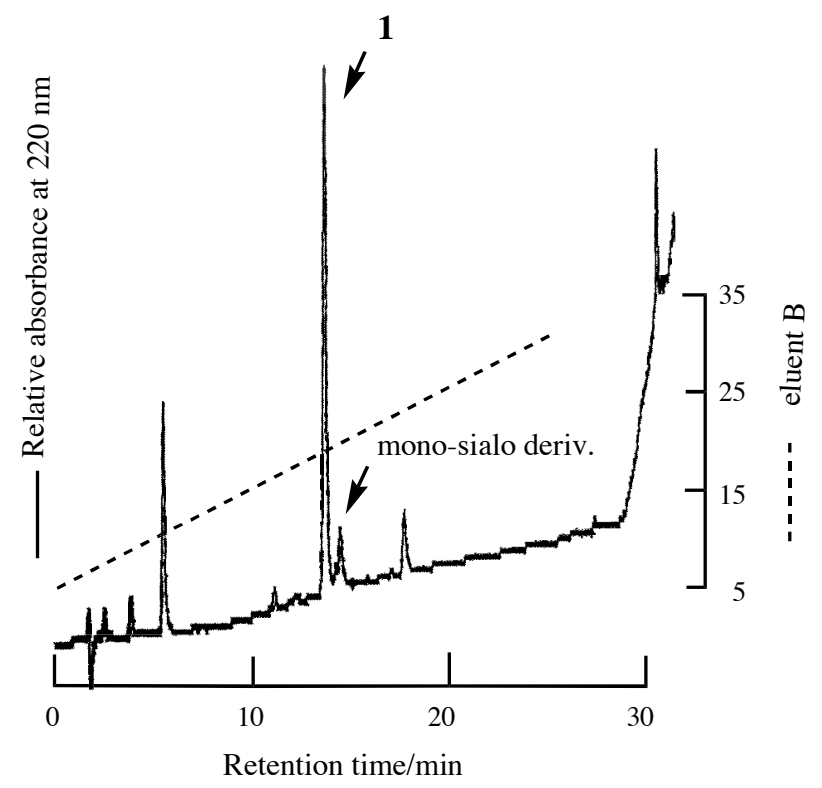

Figure 3. HPLC of glycopeptides 1. Column: Mightysil, RP-18 (150x4.6 mm), Eluent A: $10 \mathrm{mM}$ ammonium acetate ( $\mathrm{pH} 5.8$ ), B: acetonitrile containing $10 \%$ eluent $\mathrm{A}$, Flow rate $1 \mathrm{ml} / \mathrm{min}$. 